\title{
THE EFFECTIVENESS AND IMPACT OF AN INTERVENTION PROGRAM ON MIGRATION AND HEALTH WITH MEXICAN UNDERGRADUATE STUDENTS
}

\author{
A eficácia e o impacto de um programa de intervenção sobre \\ Migração e Saúde com estudantes mexicanos de graduação
}

\author{
María Elena Rivera-Heredia* \\ Diana Tamara Martínez-Ruiz** \\ Ericka Ivonne Cervantes-Pacheco*** \\ Nydia Obregón-Velasco ${ }^{* * *}$
}

\begin{abstract}
Migration has psychological impact on those that migrate, and on their families left behind. We evaluate an intervention program to strengthen individual, social, and family resources in 120 Mexican undergraduate students with migration in their families. The study was a quasi-experimental design. Data was gathered before, during, at the end, of the intervention and a year after. Depressive symptomatology, individual, social and family resources scales were evaluated. Participants increased their individual, social, and family resources, and decreased their depressive symptomatology more than the control group. We concluded that interventions within an educational and reflective open discussion space will help to address psychosocial problems in immigrant families member left behind.
\end{abstract}

Keywords: migration; mental health; Mexican; intervention program.

Resumo. A migração tem um impacto psicológico naqueles que migram e em suas famílias deixadas para trás. Avaliamos um programa de intervenção para fortalecer recursos individuais, sociais e familiares em 120 estudantes de graduação mexicanos com casos de migração em suas famílias. $O$ estudo foi um projeto quase experimental. Os dados foram coletados antes, durante, ao final da intervenção e um ano depois. Foram avaliadas a sintomatologia depressiva e escalas de recursos individuais, sociais e

* Profesora Investigadora de la Universidad Michoacana de San Nicolás de Hidalgo. Morelia, Michoacán, México. E-mail: maelenarivera@gmail.com. Orcid: 0000-0002-5835-0789.

** Directora de la Escuela Nacional de Estudios Superiores (ENES), Unidad Morelia. Morelia, Michoacán, México. E-mail: tamaramartinezruiz@gmail.com. Orcid: 0000-0003-1893-4613.

*** Profesora Investigadora de la Universidad Michoacana de San Nicolás de Hidalgo. Morelia, Michoacán, México. E-mail: erickapsic@gmail.com. Orcid: 0000-0003-2498-6815.

${ }^{* * * *}$ Profesora Investigadora de la Universidad Michoacana de San Nicolás de Hidalgo. Morelia, Michoacán, México. E-mail: nyboe07@yahoo.com.mx. Orcid: 0000-0002-1038-914X. 
familiares. Os participantes aumentaram seus recursos individuais, sociais e familiares e diminuíram sua sintomatologia depressiva mais do que o grupo de controle. Concluímos que intervenções dentro de um espaço de discussão aberta educacional e reflexiva ajudarão a abordar problemas psicossociais em membros de famílias imigrantes deixados para trás.

Palavras-chave: migração; saúde mental; mexicano; programa de intervenção.

\section{Introduction}

For more than 100 years there has been a continuous movement of people from México to the United States of America (Fernández-Guzmán, 2013). There are 38 million immigrants in the United States of America; 11.2 million of them were born in Mexico (Wallace et alii, 2007). In recent years migration patterns between these two countries changed, because of the economic recession in the USA (Pew Research Center, 2017). Recently the return of migrants to their country of origin is more often (Gulbas et alii, 2015). Also, many Mexican migrants used to work some months or years in the USA and then return to their communities, staying there for several months or years, and then returning to the United States of America. The same process often recurred several times, and has been called "circular migration" (Lázaro-Castellanos, 2018; Vertovec, 2006). However, since the border has been restricted, the possibility of circular migration reduced. Three situations arise: 1) one part of the family is in one country and the rest part in a different country, 2) immigrants intend to bring with them as many family members as they can in order to stay together, 3 ) immigrants return to Mexico for their own will, or by repatriation.

The state of Michoacán in Mexico, has a high tradition of migration; the population has decreased in 86 of the 113 counties because of this phenomenon; there is internal migration from small towns to bigger ones, or from one city to other, and external migration, which is mainly to the USA and occasionally to Canada (CONAPO, 2016; INEGI, 2011). There are people from Michoacán in almost every state in the USA, most of them are in California, Texas, Illinois, New Mexico, Arizona and Florida (Secretaría del Migrante del Estado de Michoacán, 2017). This context can explain why Michoacán has a significant number of homes with grandparents, aunts, and uncles taking care of the children of the migrants.

Relatives of Mexican migrants who work in the United States say the advantages of migration are mainly occupational and economic (better quality of life, money to pay for schooling of children, more earning potential). However, relatives also mention disadvantages, like family disintegration, pain, sadness, loss of contact, or abandonment (Obregón-Velasco, Rivera-Heredia, 2015; Obregón-Velasco et alii, 2014; Wilkerson, Yamawaki, Downs, 2009). 
The same experiences have been called "the emotional costs of migration" (Aresti de la Torre, 2010).

Multiple scholars have been studied the psychosocial consequences of migration (Aguilera-Guzman, Garcia, Garcia, 2004; Breslau et alii, 2007; Falicov, 2007; Farley et alii, 2005; Grzywacz et alii, 2006; Pérez-Padilla, RiveraHeredia, 2017). Most of them consider that migration of a family member is a stressful life event that is accompanied by many changes and challenges in the migrants and in their family's lives.

To understand family stress associated with migration we can consider the Double ABC-X Model from McCubbin and Patterson (1983), which is an adaptation of Ruben Hill's ABC Theory (Hill, 1949). The ABC-X model says that internal family resources and informal or formal social supports are an important influence in determining whether a stressful family life event, like the migration of a family member will become a crisis. Family perception and parental self-efficacy are also important elements to consider. The Double ABC-X model addresses accumulated demands of several stressors, the influence of adaptive resources, and the perception of coherence (Leave, McCubbin, Patterson, 2002). This information will tell us if it there has been good adaptation or a maladaptation in the multiple experiences related to migration, such as family separations and reunifications (Gulbas et alii, 2015; Falicov, 2007).

People need to learn how to deal with stress, and how to manage the several feelings and consequences of migration in their lives (Pérez-Padilla, Rivera-Heredia, 2017). Even though there are some studies about intervention programs, rarely these programs are focused on migrant's family members that remain in their country of origin, some exceptions are the studies of Mummert (2018); Martínez-Ruiz, Rivera-Heredia (2017); and Obregón (2017).

For instance, some studies have addressed the reduction of depressive symptomatology in adolescents (Moscardino et alii, 2010). There are other interventions focused in the meaning of change and the attitudes toward change (Bouckenooghe, 2010), and studies targeted to the persons who deliver the intervention programs (Shek, Wai, 2008; Newman-Carlson, Horne, 2004).

Important targets in most of the intervention programs have been to promote health (Inman et alii, 2011; Mummert, 2018), promote positive emotions (Cohn, Frederikson, 2010), promote resilience (OECD, 2018; Noether et alii, 2007), and increase psychological resources (Obregón, 2017).

This background leads us to think about what could we do to help migrant family's members that remain in Mexico? To answer that question, we elaborated and evaluated an intervention program based on health promotion (Inman et alii, 2011; Kremser, 2010) with the following theoretical strategy: If the participants receive an intervention with health promotion approach that 
will strengthen individual, social, and family resources, then the individuals and the families left behind will have more elements to cope with stress and the challenges associated to this process.

Intervention programs about migration and health targeted to college students living in the Mexican context have not been done or evaluated previously. Even dough previous studies with this population reported depressive symptomatology in students when they have migration experience in direct family members, such as their parents, grandparents, brothers and sisters (Rivera-Heredia et alii, 2012). Because of that, it is necessary to evaluate the effects of an intervention program on migration and health used in this study with Mexican college students, and more specifically, to know which is the best way to deliver the intervention (with oral presentation or with group discussions) and measure its effectiveness. Therefore, our research questions were:

1. Does the intervention increase individual, social and family resources?

2. Does the intervention decrease depressive symptomatology in the participants?

3. Which is the most effective format of intervention, 1) oral presentations, 2) group discussions, 3) both, or 4) neither?

4. Does the sequence of the formats affect the outcome of the intervention?

5. After one year, what do the participants think about how helpful the intervention was?

Considering the hypothesis: the intervention will increase the individual, family and social resources, and will decrease the depressive symptomatology in the participants. Both formats of the interventions will have similar effectiveness and the sequence of the components will not affect the outcome of the intervention. After one year, the participants of the intervention will evaluate it positively.

\section{Methods}

\section{Study design and characteristics of participants}

The study was conducted in a natural environment inside a university classroom in Morelia, Michoacán, México during 14 weeks, on 2009. The follow up was on 2010. The sample consisted of 120 undergraduate students having as a major in Psychology. They were in their third year of college. The students receiving the intervention were taking an elective course on migration. The students in the control group were also in the same semester but were enrolled in another course. 
This was a quasi-experimental design (Nestor, Schutt, 2019) with two intervention components and three measurements with correlated samples (Table 1). The effect of each type of intervention was analyzed and compared with each other as well as the sequence effect.

\section{Table 1: Study design, participants, format of intervention and time of evaluation}

\begin{tabular}{c|c|c|c|c|c|c}
\hline Group & $\begin{array}{c}\text { Initial } \\
\text { evaluation }\end{array}$ & $\begin{array}{c}\text { Format and } \\
\text { sequence of the } \\
\text { intervention }\end{array}$ & $\begin{array}{c}\text { Process } \\
\text { evaluation }\end{array}$ & $\begin{array}{c}\text { Type and } \\
\text { sequence of the } \\
\text { intervention }\end{array}$ & $\begin{array}{c}\text { Final } \\
\text { evaluation }\end{array}$ & $\begin{array}{c}\text { Follow- } \\
\text { up }\end{array}$ \\
\hline $\begin{array}{c}\mathbf{1 .}(\mathbf{A}+\mathbf{B}) \\
\mathbf{n = 4 0}\end{array}$ & Yes & $\begin{array}{c}\text { A-Directive } \\
\text { Oral } \\
\text { presentations }\end{array}$ & Yes & $\begin{array}{c}\text { B-Non-directive } \\
\text { Group } \\
\text { discussions }\end{array}$ & Yes & Yes \\
\hline $\begin{array}{c}\mathbf{2 .}(\mathbf{B}+\mathbf{A}) \\
\mathbf{n = 4 0}\end{array}$ & Yes & $\begin{array}{c}\text { B-Non-directive } \\
\text { Group } \\
\text { discussions }\end{array}$ & Yes & $\begin{array}{c}\text { A-Directive } \\
\text { Oral } \\
\text { presentations }\end{array}$ & Yes & Yes \\
\hline $\begin{array}{c}\mathbf{3 . ~ C o n t r o l} \\
\mathbf{n = 4 0}\end{array}$ & Yes & No intervention & No & No intervention & Yes & No \\
\hline
\end{tabular}

Two styles or type of interventions were used. In the directive intervention (A), the professor showed the students oral presentations with a different topic for each class. In the non-directive intervention (B) the professor elicited group discussion of the same topics. The groups had a different facilitator. Each intervention style or type lasted 8 sessions with two hours of duration. Group 1 had the directive intervention and then the non-directive intervention ( $A+B$ sequence), and Group 2 had the non-directive intervention and then the directive intervention ( $\mathrm{B}+\mathrm{A}$ sequence). The themes were 1$)$ psychological and sociocultural processes related to migration; 2) raising children in families with migrant experience; 3) emotions in crisis situations (stress, depression, and anxiety); 4) psychological resources; 5) trans-cultural skills; 6) violence prevention; 7) social support networks; and 8) main health problems of migrants.

In the initial evaluation 120 students participated. From the 80 students that were part of the experimental groups, 75 participated $(94 \%)$ in the intermediate evaluation, and 102 of the 120 participated (85\%) in the final evaluation.

In the follow-up study we obtained data from $44 \%$ of the participants from the intervention groups (35 from 80).

\section{Measures}

The following scales and questionnaires were administrated to the two groups of participants at the beginning of the intervention program, after the first component, and at the end of the second component. 
Migration and Health in the Family Questionnaire. It addressed which relatives that have migrated, where they have settled, advantages and disadvantages of migration, nature of relationship with the migrant, health changes associated with migration, and main health problems in family members.

Family Resources. We used the Intrafamiliar Relations Evaluation Scale (Rivera-Heredia, Andrade, 2010) which has three dimensions: unity and support $(\alpha=.85)$, expression $(\alpha=.87)$, and difficulties $(\alpha=.73)$. This Likert scale employs five options, from total agreement to total disagreement.

Individual and Social Resources. We used three self-report scales to measure affective $(\alpha=.82)$, cognitive $(\alpha=.77)$, and social $(\alpha=.75)$ resources (Rivera-Heredia, Andrade, Figueroa, 2006) respectively. Affective and cognitive resources were considered individual resources. The affective resources scale dimensions were self-control, sadness management, anger management, and recuperation of balance. The cognitive resources scale dimensions were problem reflection, religious beliefs, and self-reproach. The social resources scale dimensions were social support networks and ability to ask for support.

Depressive Symptomatology. Revised version CESD-R (Eaton et alii, 2004; Radloff, 1977; Reyes et alii, 2003). This scale has 35 items, Response values for each question were: Not at all or less than one day $=0 ; 1-2$ days $=1 ; 3-4$ days $=2 ; 5-7$ days $=3$; and Nearly every day for 2 weeks $=4$. In this study 15 of the 35 items were included in order to keep a high level of reliability. The Cronbach's alpha at the beginning of the intervention was .85, after the first component or directive style it was .84, and at the end of the intervention it was .85.

In the follow up measurement, an Impact Evaluation Scale (RiveraHeredia, 2010) and a Questionnaire elaborated for this study to measure the impact of the intervention were administrated to the participants.

Impact evaluation Scale. Adapted to a 18-item from the Audiovisual Messages Impact Evaluation Scale (Rivera-Heredia, 2010). This Likert scale employs options ranging from 1 to 5 , where 5 is total agreement and 1 is total disagreement. It measured affective and cognitive impact, we included the following dimensions: reflection $(\alpha=.86)$, resources $(\alpha=.77)$, cognitive impact $(\alpha=.76)$, novelty $(\alpha=.81)$, and quality $(\alpha=.81)$.

Intervention Impact Questionnaire. The questionnaire asked their opinions about the intervention. Some examples of the items are: What is your general impression of taking this intervention program? Which format of the intervention was more helpful for your personal and professional development? Which of the topics of this intervention program have you applied in your life? 


\section{Procedures and ethics}

Two groups received an intervention on migration and health, and the third group was the control. The professors teaching the migration course were part of the research team. They first explained the objectives and structure of the intervention. All students agreed and then signed a consent form in order to voluntarily participate in this research. The interventions took place in the classroom during 19 sessions [ 1 (evaluation) +8 (intervention A) + 1 (evaluation) +8 (intervention B) +1 (evaluation)], from February to August. The contents of the interventions are described in Rivera-Heredia, Obregón-Velasco, Cervantes-Pacheco y Martínez-Ruiz (2014). The students who participated took this intervention as an optional course titled "psychosocial problems of migration". They were not evaluated with written or oral examinations. Their final grades depended on their participation and assistance, and also on their report dairies, in which they described their experiences and thoughts about each session. At the end of the intervention small groups of the participants designed a table game, about migration and health, the delivery of that was their final work for the course.

\section{Data analysis}

To evaluate the effects of the different intervention components, we used a $t$-test for correlated samples. We compared the groups at the beginning of the intervention, at the end of the first component (A or B), and again at the end of the second component. We then compared the initial evaluation with the final one. We used an ANOVA test to determine whether the initial conditions of the three groups were the same in the initial evaluation and at the end of the interventions $(A+B$ or $B+A)$. All these analyses were done using the Statistical Package for Social Sciences (SPSS 17.0, 2008). The power analysis was done with JMP (Stata, 2012).

\section{Results}

In order to answer the question does the intervention increase individual, social and family resources? We compared the scores of Group 1 (Oral presentations + group discussions), Group 2 (Group discussions + oral presentations), Group 3 (control group) and a combination of groups integrated Group 4 (Group 1 + Group 2). We found that the participants in the intervention groups increased their affective, cognitive, social, and family resources more than the control group in self-control, sadness management, recuperation of balance, self-reproach, and expression in the family. Social networks scores were marginal or close to be statistically significant (Table 2).

When we compared psychological and family resources between the intervention groups and the control group, we found that the size effect of the 
significant differences that were found was medium in self-control (Cohen's D of group $1=0.59$ and from group $4=0.30$ ), sadness management (Cohen's D of group $1=-0.44$ ), anger management (Cohen's D of group $1=0.40$ ), recuperation of balance (Cohen's $\mathrm{D}$ of group $1=0.59$; group $2=0.32$ and group $4=0.43$ ), problem reflection (Cohen's $\mathrm{D}$ of group $1=0.56$; group $2=$ 0.35), and self-reproach (Cohen's D of group $1=-.56$ ).

The power analysis was calculated with one subscale of family resources (expression) and it was $42 \%$, and with one subscale of affective resources (self-control) was $41.7 \%$ of power.

Table 2: Individual, social and family resources: initial versus final

\begin{tabular}{|c|c|c|c|c|c|c|c|c|c|c|c|c|c|c|c|c|c|}
\hline & & \multicolumn{4}{|c|}{ Group 1} & \multicolumn{4}{|c|}{ Group2 } & \multicolumn{4}{|c|}{ Group3 } & \multicolumn{4}{|c|}{ Group 4} \\
\hline & Evaluation & Media & $N$ & $S D$ & $P$ & Media & $N$ & $S D$ & $P$ & Media & $N$ & $S D$ & $P$ & Media & $N$ & $S D$ & $P$ \\
\hline \multirow[t]{2}{*}{ Self-control } & A & 3.34 & 29 & .39 & $.00 *$ & 3.37 & 38 & .42 & .22 & 3.41 & 31 & .38 & .19 & 3.36 & 67 & .40 & $.00^{*}$ \\
\hline & C & 3.57 & 29 & .39 & & 3.45 & 38 & .52 & & 3.50 & 31 & .39 & & 3.50 & 67 & .47 & \\
\hline \multirow[t]{2}{*}{$\begin{array}{l}\text { Sadness } \\
\text { management }\end{array}$} & A & 2.16 & 29 & .80 & $.02 *$ & 2.21 & 38 & .74 & .32 & 1.97 & 31 & .57 & .73 & 2.19 & 67 & .76 & $.02 *$ \\
\hline & C & 1.84 & 29 & .73 & & 2.10 & 38 & .71 & & 2.00 & 31 & .57 & & 1.99 & 67 & .72 & \\
\hline \multirow{2}{*}{$\begin{array}{l}\text { Anger } \\
\text { management }\end{array}$} & A & 2.23 & 26 & .36 & $.06^{5}$ & 2.29 & 38 & .46 & .66 & 2.32 & 31 & .46 & .34 & 2.27 & 67 & .42 & .41 \\
\hline & C & 2.44 & 26 & .52 & & 2.25 & 38 & .43 & & 2.25 & 31 & .28 & & 2.33 & 67 & .48 & \\
\hline \multirow{2}{*}{$\begin{array}{l}\text { Recuperation } \\
\text { of balance }\end{array}$} & A & 3.37 & 29 & .57 & $.02^{*}$ & 3.35 & 38 & .70 & $.04 *$ & 3.42 & 31 & .64 & .11 & 3.36 & 67 & .64 & $.00^{*}$ \\
\hline & C & 3.63 & 29 & .44 & & 3.52 & 38 & .53 & & 3.53 & 31 & .51 & & 3.57 & 67 & .49 & \\
\hline \multirow{2}{*}{$\begin{array}{l}\text { Problem } \\
\text { reflection }\end{array}$} & A & 3.62 & 29 & .36 & .76 & 3.33 & 38 & .59 & $.01^{*}$ & 3.51 & 31 & .48 & .77 & 3.46 & 67 & .52 & $.01^{*}$ \\
\hline & C & 3.64 & 29 & .36 & & 3.57 & 38 & .43 & & 3.53 & 31 & .54 & & 3.60 & 67 & .40 & \\
\hline \multirow{2}{*}{$\begin{array}{l}\text { Self- } \\
\text { reproach }\end{array}$} & A & 2.01 & 29 & .75 & $.00 *$ & 2.28 & 38 & .78 & .37 & 1.97 & 31 & .67 & .72 & 2.16 & 67 & .77 & $.02^{*}$ \\
\hline & C & 1.68 & 29 & .59 & & 2.17 & 38 & .77 & & 1.94 & 31 & .71 & & 1.96 & 67 & .74 & \\
\hline \multirow[t]{2}{*}{$\begin{array}{l}\text { Religious } \\
\text { beliefs }\end{array}$} & A & 2.63 & 29 & 1.02 & .95 & 2.74 & 38 & .96 & .81 & 2.60 & 31 & .99 & .48 & 2.69 & 67 & .98 & .83 \\
\hline & C & 2.64 & 29 & 1.13 & & 2.76 & 38 & 1.01 & & 2.53 & 31 & 1.00 & & 2.71 & 67 & 1.06 & \\
\hline \multirow{2}{*}{$\begin{array}{l}\text { Social } \\
\text { support } \\
\text { networks }\end{array}$} & A & 3.73 & 29 & .47 & .53 & 3.43 & 38 & .81 & $.07^{5}$ & 3.64 & 31 & .47 & .77 & 3.56 & 67 & .70 & $.06^{s}$ \\
\hline & C & 3.78 & 29 & .35 & & 3.59 & 38 & .67 & & 3.66 & 31 & .49 & & 3.68 & 67 & .56 & \\
\hline \multirow{2}{*}{$\begin{array}{l}\text { Ability to ask } \\
\text { for support }\end{array}$} & A & 1.48 & 29 & .53 & .62 & 1.86 & 38 & .74 & .12 & 1.46 & 31 & .53 & .42 & 1.70 & 67 & .68 & .26 \\
\hline & C & 1.52 & 29 & .56 & & 1.71 & 38 & .75 & & 1.54 & 31 & .54 & & 1.63 & 67 & .68 & \\
\hline \multirow{2}{*}{$\begin{array}{l}\text { Union and } \\
\text { support }\end{array}$} & A & 4.17 & 29 & .62 & .21 & 4.07 & 38 & .73 & .38 & 4.17 & 33 & .76 & .96 & 4.12 & 67 & .68 & .14 \\
\hline & $c$ & 4.33 & 29 & .65 & & 4.19 & 38 & .83 & & 4.18 & 33 & .72 & & 4.25 & 67 & .76 & \\
\hline \multirow[t]{2}{*}{ Expression } & A & 4.09 & 29 & .80 & .14 & 3.99 & 38 & .80 & $.06^{5}$ & 3.94 & 33 & .88 & .52 & 4.03 & 67 & .80 & $.02^{*}$ \\
\hline & C & 4.25 & 29 & .65 & & 4.17 & 38 & .78 & & 4.05 & 33 & .84 & & 4.20 & 67 & .72 & \\
\hline
\end{tabular}

$\mathrm{A}=$ Initial Evaluation; $\mathrm{C}=$ Final Evaluation

$*=$ significant at .05; ${ }^{\mathrm{s}=}$ marginal (between .05 and .09) $; ~=$ Difficulties or negative resources 
Related to the question does the intervention decrease depressive symptomatology in participants? We found that in group 1, there were significant differences in depressive symptomatology between the intermediate evaluation and the final one, as in the initial evaluation and the final evaluation (Intermediate mean $=1.85$ vs. final mean $=1.79 ; \mathrm{t}=2.117 ; \mathrm{df}=26 ; \mathrm{p}=$ .044 ; and Initial mean $=1.84$ vs. Final mean $=1.67 ; \mathrm{t}=3.879 ; \mathrm{df}=26 ; \mathrm{p}=$ .001). The lower scores indicate less depressive symptomatology. The effect size measured with Cohen's D was medium (-0.43).

There were no significant differences in depressive symptomatology between group 1 and 2. However, in the comparisons between depressive symptomatology at the beginning and at the end of the program there is a clear tendency to reduce depressive symptomatology (Initial mean $=2.02$, final mean $=1.93 ; \mathrm{t}=1.73 ; \mathrm{df}=35 ; \mathrm{p}=.09$ ).

When we compare both intervention groups (named group 4) against the control group, there was a significant difference between the initial scores and the final ones in depressive symptomatology, which decreased after the treatment $(\mathrm{n}=62$, initial mean 1.93, final mean $=1.81, \mathrm{df}=62 ; \mathrm{t}=3.16 ; \mathrm{p}$ $=.002)$.

There were no positive changes in the control group on depressive symptomatology between initial and final scores (1.78 vs. 1.85). On the contrary the scores increased instead of decreased.

In regards to the research questions which is the most effective type of intervention? And does the sequence of the formats affect the outcome? We found that both components are more effective together than either component alone, so the sequence of the intervention is not as important as the conjunction of oral presentation and discussion groups, having less depressive symptoms when oral presentation followed group discussion.

In the following up stage, with the question: After one year, what do the participants think about the intervention? high scores were in: reflection $($ mean $=4.56)$, quality $($ mean $=4.36)$, resources $($ mean $=4.30)$, novelty $($ mean $=$ $4.15)$, and cognitive impact (mean $=4.12$ ). Moreover, there were no statistical differences between the participants from group 1 and group 2 in any of the previously mentioned dimensions.

The most meaningful sessions reported by the participants were: Emotions in Crisis Situations, The Psychological and Sociocultural Processes Related to Migration, and Individual, Social and Family Resources. Some of the participant's comments about the intervention were:

Woman, 23 years old: "I realized how does the migrants feel, and what are the situations they have to affront" [Me di cuenta de lo que sienten los migrantes y de lo que tienen que enfrentar]. 
Man, 24 years old: "It opened my eyes and made me reflect" [Me abrió los ojos y me hizo reflexionar].

Woman 24 years old: "I valued the changes of the behaviors of my brothers since they migrated, because each of them had his own motivation, and migration is not easy" IValoré los cambios en el comportamiento de mis hermanos a partir de la migración, porque cada uno tuvo su motivo, y no es fácil migrar].

A strong recommendation from the participants was to combine both oral presentations and and group discussion in each session.

\section{Discussion}

When we compared initial scores with final scores in the intervention groups and the control group, we found that the intervention groups had higher final scores for individual, and family resources such as self-control, sadness management, recuperation of balance, problem reflection, self-reproach, and expression in the family. Also, there were marginal changes in anger management and social support network. The direction of the change of the scale of anger management was opposite than expected.

These results contribute to have quantitative evidence and not only qualitative evidence (as it was reported in previous studies such as Martínez-Ruiz et alii, 2017 and Obregón-Velasco et alii, 2014) that the intervention on Migration and Health helps to increase psychological Resources in college students who have migrant relatives.

We did not find any significant differences between groups in religious beliefs, in the ability to ask for support, or in unity and support from the family. Depressive symptomatology decreased significantly in the intervention groups, but did not decrease in the control group. This confirms our hypothesis.

The two components of the intervention were more effective together than either component alone, probably longer intervention (16 sessions) provided more time for health promotion, for the strengthening of personal social and family resources, and for the diminution of depressive symptomatology.

We found a tendency of positive changes at the process evaluation applied after the first 8 sessions, but as Hobfoll, Walter and Horsey (2008, p. 308) say "dose and fit are vital to intervention success", in this case, more sessions will increase the positive changes. We confirm that the duration of the intervention is important to consider when interventions are applied in educational settings like this.

The sequence of format was not as important as the presence of both. However, providing the oral presentation followed by the group discussions was more effective. These results have pedagogic implications related to the 
learning style of the participants and their previous learning experiences, and can be important findings for future intervention designs for this kind of population.

The follow-up indicates that the participants valued the intervention as a learning experience that helped them to understand more about migration and how the migrants and their families live. The comments from the participants presented in the results are evidence than the intervention targeted their goal and was successful.

The themes that were consider most important for the participants were: a) emotions in crisis situations (stress, depression and anxiety); b) the psychological and socio-cultural processes related to migration; and c) individual, social and family resources. Thus, the participants, as Falicov (2007) suggested, cared more about to psychological and socio-cultural issues related to the migration experience. This will be an important route that we have to keep working in the future.

The intervention that we studied was an evidence-based health promotion program for school and communities such as those studied by Kremser (2010) and Inman et alii (2011).

Because our intervention was done in a natural environment we had to adapt it to ambient schedule constraints. In particular, because of the school calendar, delivery of the intervention was interrupted by events such as holidays and spring break. Nevertheless, the intervention program was completed.

A limitation of this study is that in the final evaluation, $15 \%$ of the participants did not answer the final test. They did not drop out of the intervention, but they were not present in the group at the moment of the final evaluation. This can be explained because the final test was applied at the last days of the school year, and some students did not assist to the school as they did at the beginning of the course. We wonder how much the outcomes could change with all the participants in the final evaluation. But we suggest to future studies to be alert to these processes in school-based interventions

Another limitation was that the power of the sample size (42\%). For the study to have enough power, the number of participants should have been 176 . Therefore, we must be cautious about the answers to the research questions. Despite the low power of the sample, the size effect of the changes using D of Cohen was in a medium level. This effect can become larger with more participants in the intervention program. In this study we confirmed our research hypothesis, and considering that we do not have enough power of the sample, we might have a type II, or beta, error (Pagano, 2006). 
Our findings can aid to the state of the knowledge in designing other intervention programs for people affected by migration as a stressful life event. Mummert (2018) and Obregón-Velasco (2017) have done similar work with different members of the migrant's family who stayed behind, but not with the age and education of this population. With the present study we contribute with an effective intervention to support college students. We think that factors contributing to the success of our intervention included the novelty of the intervention, the health promotion approach, the link between the topics and the participants' personal experiences, the organization of the delivery of the intervention, and the characteristics of the instructors of the intervention groups. These elements should be studied in the future research.

Another strength of this study was its design (Nestor, Schutt, 2019), because the inclusion of two intervention groups and a control group can help in determining whether significant differences in the means of the groups of the variables studied were due to the contents of the intervention or because of the presence of another variable.

Given the increase in depressive symptomatology in the general population, and especially in people with migrant relatives (Rivera-Heredia et alii, 2012; Wilkerson et alii, 2009), the diminishing of depressive symptomatology in the intervention groups was an important significant finding and one of the major achievements of this study.

Although intervention programs targeting some other health issues are well established, this study is a pioneering evidence-based intervention program on migration and health in Mexican College students. The participants in the intervention groups increased their individual and family resources, and decreased their depressive symptomatology, more than those in the control group. We conclude that such interventions can aid participants' mental health and address a substantial psychosocial problem.

\section{References}

AGUILERA-GUZMÁN, Rosa María; CARREÑO-GARCÍA, María Silvia; JUÁREZGARCÍA, Francisco. Características psicométricas de la CES-D en una muestra de adolescentes rurales mexicanos de zonas con alta tradición migratoria. Salud Mental, v. 27, n. 6, p. 57-66, 2004.

ARESTI DE LA TORRE, Lore. Mujer y Migración: Los Costos Emocionales. México: Universidad Autónoma Metropolitana, Universidad Autónoma de Nuevo León, Universidad Michoacana de San Nicolas de Hidalgo, 2010.

BANCO DE MÉXICO. Yearbook of migration and remitancees. México: Banco de México, 2017. Available at: <https://www.gob.mx/cms/uploads/attachment/ file/250390/Anuario_Migracion_y_Remesas_2017.pdf > .

BOUCKENOOGHE, Dave. Positioning Change Recipients' Attitudes Toward Change 
In The Organizational Change Literature. The Journal of Applied Behavioral Science, v. 46, n. 4, p. 500-531, 2010.

BRESLAU, Joshua; AGUILAR-GAXIOLA, Sergio; BORGES, Guilherme; KENDLER, Kenneth; SU, Maxwell; KESSLER, Ronald C. Risk for psychiatric disorder among immigrants and their US-Born Descendants: evidence from the national comorbidity survey replication. Journal of Nervous and Mental Disease, v. 195, n. 3, p. 189-195, 2007.

CONAPO. Prontuario sobre movilidad y migración internacional. Dimensiones del fenómeno en México. México: Secretaría de Gobernación, Unidad de Política Migratoria y Consejo Nacional de Población, 2016.

COHN, Michael; FREDRICKSON, Barbara L. In search of durable positive psychology interventions: predictors and consequences of long-term positive behavior change. Journal of Positive Psychology, v. 5, n. 5, p. 355-366, 2010.

EATON, William W.; SMITH, Corey; YBARRA, Michele; MUNTANER, Carles; TIEN, Allen. Center for Epidemiologic Studies Depression Scale: review and revision (CESD and CESD-R). In: MARUISH, Mark (ed.). The Use of Psychological Testing for Treatment Planning and Outcomes Assessment. 3rd ed., v. 3: Instruments for Adults. Mahwah, NJ: Lawrence Erlbaum, 2004, p. 363-377.

FALICOV, Cecilia. Working with Transnational Inmigrants: expanding meanings of family, community and culture. Family Process, v. 46, n. 2, p. 157-171, 2007.

FARLEY, Tillman; GALVES, Al; DICKINSON, Miriam; DÍAZ-PÉREZ, María de Jesús. Stress, coping, and health: a comparison of Mexican immigrants, MexicanAmericans, and Non-Hispanics. Journal of Immigrant Health, v. 7, n. 3, p. 213220, 2005.

FERNÁNDEZ-GUZMÁN, Eduardo. Más allá de eventos coyunturales. La Migración México-Estados Unidos: un fenómeno de larga duración. Revista Acta Universitaria, n. 23 (NE 1. Procesos Migratorios), p. 1-26, 2013.

GULBAS, Lauren; ZAYAS, Luis; YOON, Hyunwoo; SZYLK, Hanna; AGUILARGAXIOLA, Sergio; NATERA, Guillermina. Deportation experiences and depression among U.S. citizen-children with undocumented Mexican parents. Child: care, health and development, v. 42, n. 2, p. 220-230, 2015. Available at: $<$ https://doi.org/10.1111/cch.12307>.

GRZYWACZ, Joseph G.; QUANDT, Sara A.; EARLY, Julie; TAPIA, Janeth; GRAHAM, Christopher N.; ARCURY, Thomas A. Leaving family for work. Ambivalence and mental health among Mexican migrant farmworker men. Journal of immigrant and minority health, v. 8, n. 1, p. 85-97, 2006.

HILL, Ruben. Families under stress. New York: Harper and Row, Publishers, 1949.

HOBFOLL, Stevan; WALTER, Kristen; HORSEY, Katie. Dose and fit are vital to intervention success. Psychiatry, v. 71, n. 4, p. 308-318, 2008.

INEGI. Cuéntame de México. Michoacán de Ocampo. Retrieved on July, 9. 2011. Available at: <http://cuentame.inegi.org.mx/monografias/informacion/mich/ poblacion $/ m_{-}$migratorios.aspx?tema $=$me\&e $=16>$. 
INMAN, Diana; VAN BAKERGEM, Karen; LAROSA, Angela; GARR, David. Evidence-based health promotion programs for schools and communities. American Journal of Preventive Medicine, v. 40, n. 2, p. 207-219, 2011.

KREMSER, Waldemar. Phases of school health promotion implementation through the lens of complexity theory: lessons learnt from an Austrian case study. Health Promotion International, v. 26, n. 2, p. 136-147, 2010.

LÁZARO-CASTELLANOS, Rosa. Migración circular de trabajadoras mexicanas hacia Estados Unidos. Desplazamientos territoriales y subjetivos. Iberoamérica Social: Revista-red de estudios sociales, v. 5, n. 9, p. 55-76, 2018.

LEAVE, Yoav; MCCUBBIN, Hamilton; PATTERSON, Joan. The double ABCX Model of Family Stress and Adaptation. An empirical Test by Analysis if Structural Equations with latent variables. In: BOSS, Pauline; MULLIGAN, Carol (eds.). Family Stress. Classic and Contemporary Readings. Thousand Oaks, California: Sage Publications, Inc., 2002, p. 123-141.

MARTÍNEZ-RUIZ, Diana Tamara; RIVERA-HEREDIA, María Elena. Los jóvenes "que se quedan": una exploración sobre el sentido de bienestar de universitarios ante el fenómeno de la migración Michoacán-EUA. Acta Universitaria, v. 27, n. 3, p. 101-114, 2017.

MCCUBBIN, Hamilton; PATTERSON, Joan. The Family Stress Process: the double ABCX model of adjustment and adaptation. Marrige and Family Review, v. 6, n. 7, p. 7-37, 1983.

MOSCARDINO, Ughetta; SCRIMIN, Sara; CAPELLO, Fabia; ALTOÈ, Gianmarco. Social support, sense of community, collectivistic values, and depressive symptoms in adolescent survivors of the 2004 Beslan terrorist attack. Social Science \& Medicine, v. 70, n. 1, p. 27-34, 2010.

MUMMERT, Gail. Atención a la salud mental de familias migrantes michoacanas: autoevaluación de intervenciones. In: RIVERA-HEREDIA, María Elena; PARDOFERNÁNDEZ, Rodrigo (coords.). Migración: Miradas y reflexiones desde la universidad. Colección del Centenario de la UMSNH. México: Miguel Angel Porrúa, 2018, p. 223-236.

NESTOR, Paul; SCHUTT, Russell. Research Methods in Psychology. Investigating Human Behavior. 3er edition, Los Angeles, California, USA: Sage, 2019.

NEWMAN-CARLSON, Dawn; HORNE, Arthur. Bully Busters: A Psychoeducational Intervention for Reducing Bullying Behavior in Middle School Students. Journal of Counseling \& Development, v. 82, n. 3, p. 259-267, 2004.

NOETHER, Chanson; BROWN, Vivian; FINKELSTEIN, Norma; RUSSELL, Lisa; VANDEMARK, Nancy; MORRIS, Laura; GRAEBER, Carla. Promoting resiliency in children of mothers with CO-occurring disorders and histories of trauma: Impact of a skills-based intervention program on child outcomes. Journal of Community Psychology, v. 35, n. 7, p. 823-843, 2007.

OBREGÓN-VELASCO, Nydia. Libro Manual de Intervención para jóvenes con familiares migrantes. México: Colofón, 2017. 
OBREGÓN-VELASCO, Nydia; RIVERA-HEREDIA, María Elena. Impacto de la migración del padre en los jóvenes: cuando la migración se convierte en abandono. Ciencia UAT, v. 10, n. 1, p. 56-67, 2015.

OBREGÓN-VELASCO, Nydia; RIVERA-HEREDIA, María Elena; MARTíNEZ-RUIZ, Diana Tamara; CERVANTES-PACHECO, Ericka Ivonne. Sucesos estresantes y sus impactos en mujeres y jóvenes de la comunidad de Cuitzeo, Michoacán. El ciclo de la migración México-EUA en sus familias. REMHU, Revista Interdisciplinar da Mobilidade Humana, v. 22, n. 43, p. 211-224, 2014.

OECD. The resilience of students with immigrant background: factors that shape well-being. OECD Review of Migrant Education. Paris: OECD Publishing, 2018.

PAGANO, Roberto. Estadística para las ciencias del comportamiento. Mexico: Thompson, 2006.

PÉREZ-PADILLA, María de la Luz; RIVERA-HEREDIA, María Elena. Salud y recursos psicológicos en migrantes retornados en zonas rurales en los Altos de Jalisco. Uaricha. Revista de Psicología, v. 14, n. 34, p. 1-16, 2007.

PEW RESEARCH CENTER. Hispanic Population Growth has leveled off since the Great Recession. 2017. Available at: < http://www.pewresearch.org/ft_17-0801 hispanicpopgrowth_featured/>.

RADLOFF, Leonor. The CES-D Scale: A Self Report Depression Scale for Research in the General Population. Appl Psychological Measurement, v. 1, p. 385-401, 1977.

REYES, Mónica; SOTO, Ana Laura; MILLA, Jessica; GARCÍA-RAMÍREZ, Adriana; HUBARD, Lucía; MENDOZA, Haydeé; MEJÍA, Lidia; GARCÍA-PEÑA, Carmen; WAGNER, Fernando. Actualización de la Escala de Depresión del Centro de Estudios Epidemiológicos (CES-D). Estudio piloto en una muestra geriátrica mexicana. Salud Mental, v. 26, n. 1, p. 59-68, 2003.

RIVERA-HEREDIA, María Elena; ANDRADE-PALOS, Patricia. Escala de evaluación de las relaciones intrafamiliares (E.R.I.). Uaricha, Revista de Psicología, v. 14, p. 12-29, 2010.

RIVERA-HEREDIA, María Elena. Psicología y comunicación visual. Estrategias para la prevención del suicidio en adolescentes. México: Trillas, 2010.

RIVERA-HEREDIA, Maria Elena; OBREGÓN-VELASCO, Nydia; CERVANTESPACHECO, Ericka Ivonne; MARTÍNEZ-RUIZ, Diana Tamara. Familia y Migración. Bienestar físico y mental. México: editorial Trillas, 2014.

RIVERA-HEREDIA, María Elena; ANDRADE-PALOS, Patricia; FIGUEROA, Angélica. Evaluación de los recursos en los adolescentes: validación psicométrica de cinco escalas. La Psicología social en Mexico, v. XI, p. 414-420, 2006.

RIVERA-HEREDIA, María Elena; CERVANTES-PACHECO, Ericka Ivonne; MARTÍNEZ-RUIZ, Diana Tamara; OBREGÓN-VELASCO, Nydia. ¿Qué pasa con los jóvenes que se quedan? Recursos psicológicos, sintomatología depresiva y migración familiar. Revista Intercontinental de Psicología y Educación, v. 14, n. 2, p. 33-51, 2012. 
SAS Institute Inc. JMP® 10 Modeling and Multivariate Methods. Cary, NC: SAS Institute Inc., 2012.

SECRETARÍA DEL MIGRANTE DEL ESTADO DE MICHOACÁN. Infografía Migración 2016. Morelia: Secretaría del Migrante, 2017.

SHEK, Daniel T. L.; WAI, C. L. Y. Training workers implementing adolescent prevention and positive youth development programs: what have we learned from the literature? Adolescence, v. 43, n. 172, p. 823-845, 2008.

SPSS. Statistical Package for the Social Sciences, 17.0. Illinois: SPSS INC.

VERTOVEC, Steven. Is circular migration the way forward in Global Policy? Around the Globe, v. 3, n. 2, p. 38-44, 2006.

WAllace, Steve P.; CASTANedA, Xochitl; GUENDELMAN, Sylvia; PADILlAFRAUSTO, Imelda; FELT, Emily; LEE, Jennifer. Immigration, Health \& Work: The Facts Behind the Myths. Los Angeles: UCLA Center for Health Policy Research, 2007.

WILKERSON, Jared; YAMAWAKI, Niwako; DOWNS, Samuel. Effects of husbands' migration on mental health and gender role ideology of rural Mexican women. Health Care for Women International, v. 30, p. 614-628, 2009. 